\title{
VISUAL IMPACTS OF STALK FORMING DIATOMS IN Grand TETON NATiOnAl PARK
}
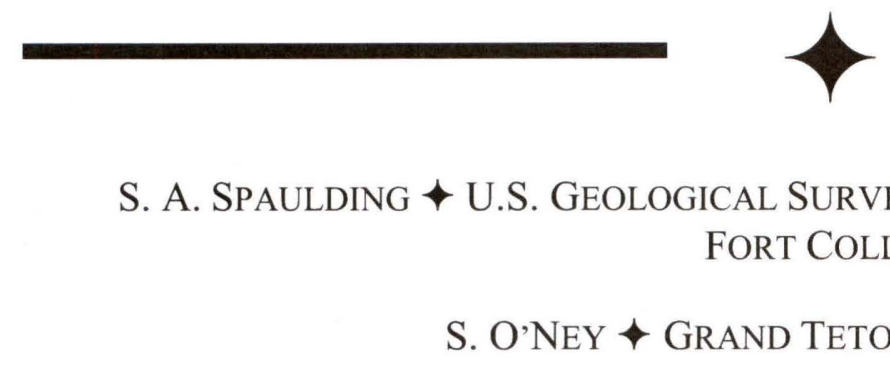
S. A. Spaulding $\downarrow$ U.S. GeOlogical Survey $\downarrow$ Fort COllins ScienCE Center FORT COLLINS

\author{
S. O’NEY $\uparrow$ GRAND TETON NATIONAL PARK
}

\section{K. Hermann $\downarrow$ U.S. EnVironmental Protection Agency, Region $8 \uparrow$ Denver}

\begin{abstract}
$\uparrow \quad$ ABSTRACT
A survey was conducted in August 2008 to determine the distribution and extent of stalked diatoms in major rivers and streams in Grand Teton National Park (GTNP). We determined that a nuisance bloom of the diatom Didymosphenia geminata was present in Lake Creek from the outlet of Phelps Lake to approximately $1 \mathrm{~km}$ downstream of the Rockefeller Preserve. This bloom was considered "excessive" because the coverage of the stream substrate was $70 \%$ or above for greater than $1 \mathrm{~km}$. This diatom species is able to survive out of water in damp conditions, and it may be transported on the gear of recreationalists. In GTNP, this diatom was found in a high visitor use area, with concomitant potential for the species to be spread by anglers to other sites within the national park. Although there are several factors that appear to influence its distribution, recent nuisance blooms of this species suggest popular angling sites are often sites of nuisance blooms. Decontamination of aquatic gear by recreationalists may be appropriate to limit the spread of nuisance blooms within the national park system and adjacent public and private water bodies.
\end{abstract}

\section{$\downarrow \quad$ INTRODUCTION}

This research presents a collaborative effort between the US Geological Survey, National Park Service, and US Environmental Protection Agency to address an issue of concern within Grand Teton
National Park (GTNP). Park managers have determined detecting the presence, abundance, and potential impacts of Didymosphenia geminata as a research goal.

The diatom Didymosphenia geminata (Lyngbye) Schmidt is emerging as an organism with an extraordinary capacity to impact stream ecosystems on a global scale. In recent years, streams in New Zealand, North America, Europe, and Asia have been colonized by unprecedented masses of "didymo" and its extracellular stalks. This diatom is able to dominate stream surfaces by covering up to $100 \%$ of substrate with thicknesses of greater than $20 \mathrm{~cm}$, greatly altering physical and biological conditions within streams. Although it is considered native to North America, this species is believed to be expanding its geographic range. Two other species of concern, Cymbella mexicana (Ehrenberg) Cleve and C. janischii A. Schmidt historically inhabit western streams and rivers (Patrick \& Reimer 1966, Wellnitz et al. 1996, Bahls 2004). The typical growth habit of all these species includes the episodic formation of large masses (Cleve 1894-1896, Skvortzow 1935, Skulberg 1982) and the rate that nuisance blooms are reported by the public and local media are increasing.

Although D. geminata occurs in both lakes and flowing waters, nuisance blooms are only known in streams and rivers. For the purposes of this study, "excessive growth" is defined as masses of cells and stalks that extend for greater than $1 \mathrm{~km}$. The masses 
may persist for several months of the year, as with several sites in North America (Spaulding \& Elwell 2007). By the use of this term "excessive", we have a working understanding that some aspect of these growths are unusual, and we consider them to be the result of a combination of biological and environmental factors.

Prior to 2007, there were no confirmed reports of D. geminata from Grand Teton National Park, although macroscopic clumps of the diatom Cymbella mexicana and $C$. janischii were documented in the rivers of Grand Teton National Park (K. Hermann, personal observations). These cymbelloid diatoms produce stalks that are close in chemical composition to $D$. geminata and may produce excessive amounts of stalks, leading to nuisance growths (Spaulding \& Elwell 2007). In the Snake River watershed, these masses occur during periods of low flow in August and September. Furthermore, the species C. mexicana and $D$. geminata are cymbelloid diatoms that are suggested to be sister taxa (Kociolek \& Stoermer 1993). That is, they are more closely related to one another than to members of either gomphonemoid or cymbelloid lineages.

The goal of this study is to determine the distribution and extent of stalked diatoms in Grand Teton National Park. The objectives are to:

- Develop an assessment of the occurrence of masses of stalked diatoms in Grand Teton National Park using a survey design that will allow estimation of extent and areal coverage.
- Evaluate survey results to determine if masses of diatoms are considered "excessive" and suggest management response.

- Assess the degree to which stalked diatoms are correlated to human impact.

- Determine if decontamination of aquatic gear by recreationalists is appropriate to contain the spread of blooms within Grand Teton National Park.

\section{$\uparrow \quad$ Methods and Materials}

Field surveys. Fieldwork was completed over 17-22 August 2008 on several tributaries and main stem of the Snake River. GIS maps with high resolution imagery and site locations (transects) were provided to field crews for location of selected sites (Figure 1). At each site, beginning with the upstream transect, three crews performed sampling activities. One crew was assigned to the left bank, one crew assigned to the right bank, and one crew assigned to cover the transect distance between the two banks (center). The center crew anchored their craft for sampling (where conditions permitted) and relocated to new positions along the transect to complete sampling activities. The bank crews secured at shore sites and accessed the transect location at the bank, wading into the stream as much as possible. Once transect sampling activities were completed, the crews moved downstream to the next transect, maintaining their respective positions (left bank, right bank, and center). At the upstream transect of each site, GPS coordinates were obtained and recorded.

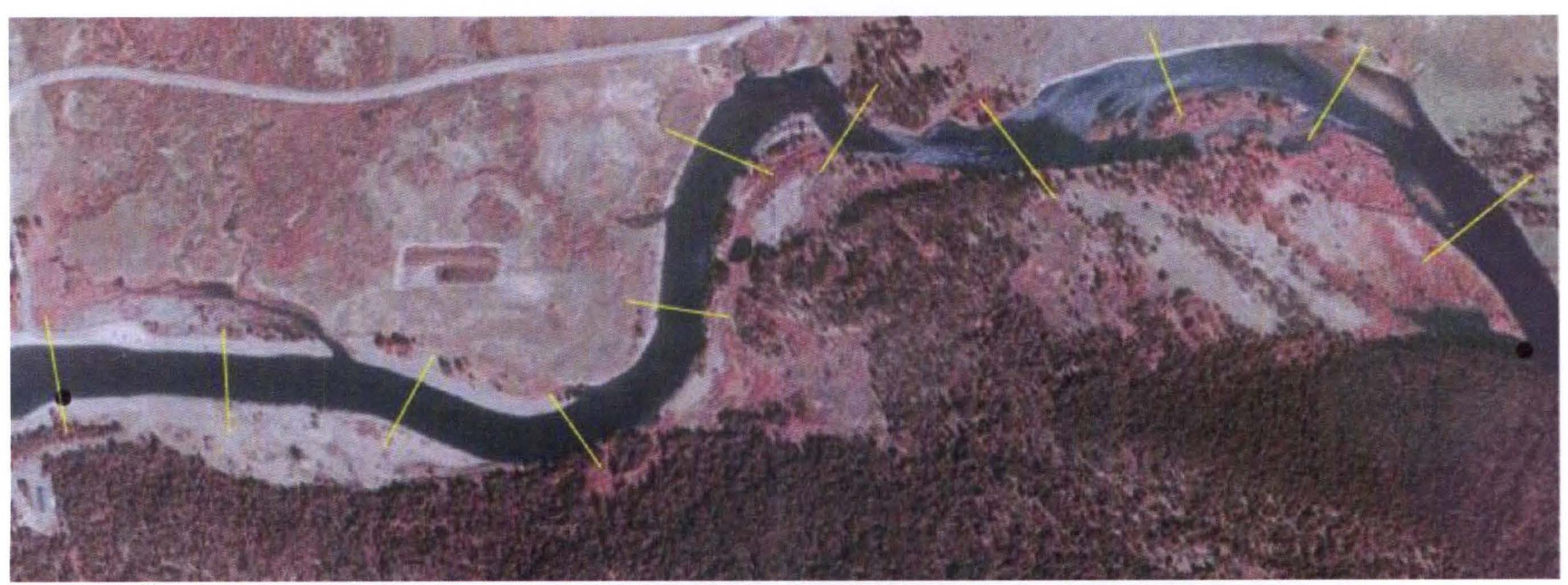

Figure 1. An example of site selection design, consisting of a series of 11 transects placed at $250 \mathrm{~m}$ separation. The site (11 transects) covers a distance of approximately 40 times the river width, based on EPA EMAP sampling protocol. 
At each transect, the following activities were completed: Each crew was issued an aerial photograph with marked, numbered transects for the site. Crews recorded site and transect number on field data sheets. Each crew recorded parameters for the transect area (10 $\mathrm{x} 10 \mathrm{~m}$ ) on the field data sheet. One person used the underwater viewing box (Nuova Rade viewer) to determine if stalked diatoms appeared to be present in the transect area and results were recorded on field data sheets. For qualitative samples, a small area from the most dominant type of stream substrate (cobble, boulder) was scraped and placed in a sample vial. For quantitative samples, a tooth brush was used to scrape an area $\left(20 \mathrm{~cm}^{2}\right)$ and collected. Quantitative measures of organic matter were estimated from 31 sites on Lake Creek and the Snake River. Samples were collected by scraping $20 \mathrm{~cm}^{2}$ of benthic cobble surfaces within the survey site and preserved in $70 \%$ ETOH. Crews estimated the percent cover of stalked diatoms over the transect area and recorded on field data sheets. Where possible, the underwater camera was used to record appearance of benthic algal mats at each site and reference numbers for photos were recorded on field data sheets. Several hundred images were taken to document benthic coverage.

Sites on Lake Creek, where macroscopic stalked diatoms were present, were rated using a modification of the Kilroy Visual Index (Larned et al. 2006). The KVI combines a measure of the average thickness of diatom stalks and the percent areal coverage on a given stream transect. We report the percent cover, because thickness was difficult to access for a large number of sites in fast flowing water. Continuous visual qualitative observations were made by two members of the field crew from Jackson Lake Dam to Dead Man's Bar. Crew members (equipped with wetsuit, mask, snorkel, fins) checked for macroscopic growths along entire reach (except in sites of water hazards). The observations confirmed that transect sites were representative of each sub-reach of the river.

Laboratory processing. Samples were processed following established methods to remove organic matter and produce permanent microslides. Organic material was oxidized using $15 \mathrm{ml}$ of $30 \% \mathrm{H}_{2} \mathrm{O}_{2}$ in a digestion over 6 days (Renberg 1990). Following the digestion, deionized water was added to bring the total volume to $50 \mathrm{ml}$. The samples were allowed to settle for 8 hours, decanted, and rinsed with deionized water 6 times to remove $\mathrm{H}_{2} \mathrm{O}_{2}$. The cleaned sediments were well mixed by shaking and $0.500 \mathrm{ml}$ was placed on glass cover slips. Two replicate cover slips were made for each of the 170 samples collected. The cover slips were allowed to dry and were mounted on glass microslides using a high refractive mounting medium (Zrax). Ashfree dry mass (AFDM) was measured on quantitative samples based on standard methods (Steinman and Lamberti, 1996).

Microscope analysis. Slides were examined under high magnification for diatom species identification using an Olympus VANOX microscope using a 100x oil objective $(\mathrm{NA}=1.4)$ and DIC. Only large stalked diatoms were included in this survey, although archiving of samples allows for future, more complete community analysis. Estimates of abundance were made at lower power $(40 \mathrm{x})$ to determine presence of large, stalk-forming species.

Permanent archives. Permanent slides and cleaned material are archived in the University of Colorado INSTAAR Diatom Database (INSTAAR Accession 10836-10999). One set of slides will be provided to Grand Teton National Park for permanent records.

Data analysis, GIS, and final report. The geographic distribution of sites, their percentage cover of stalked diatom species, and species identification were used to produce a distribution map for Grand Teton National Park using ARC GIS.

\section{$\uparrow \quad$ Results}

Visual field surveys showed a bloom of $D$. geminata present on Lake Creek during the survey period in August 2008. Coverage of D. geminata ranged from $20 \%$ of the stream transect at the outlet of Phelps Lake to $100 \%$ coverage at several sites downstream (Figure 2). Sites were surveyed in detail above and below the bridge crossing Lake Creek, showing that high coverage ( $>60 \%$ ) of the substrate occurred at both high and lower survey resolution. The bloom appeared to decline at the lowest site below Rockefeller Preserve, although we were not able to follow it to its decline, because of concern over crossing into private property. 

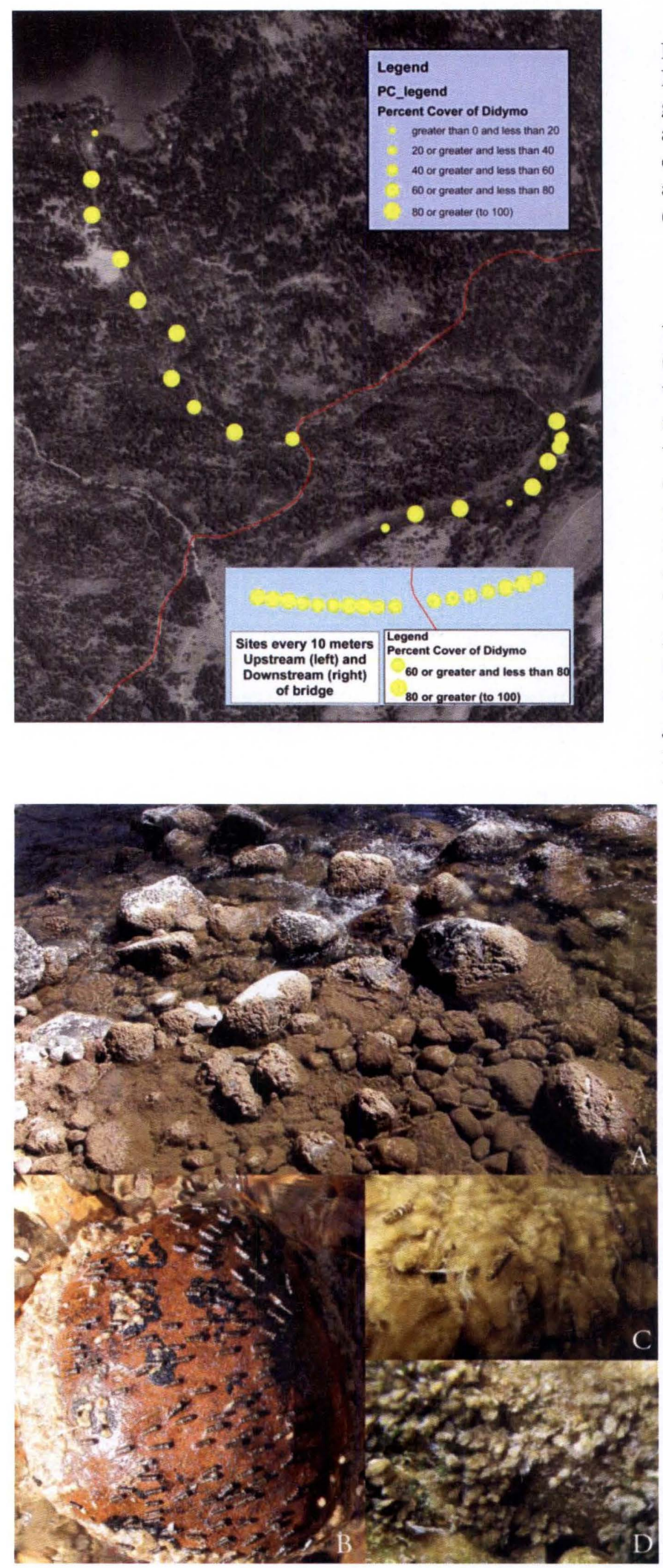

Figure 2. Image of the section of Lake Creek from Phelps Lake to below the Rockefeller Preserve. Macroscopic growths of $D$. geminata were present at all sites surveyed and the percent cover is indicated by the size of the solid circles. The inset shows the results from the detailed survey above and below the road and bridge crossing Lake Creek (red line).

The bloom of $D$. geminata in Lake Creek was typical of blooms from other sites in North America (Figure 3). Furthermore, many of the stalks were above water level, indicating that streamflow had declined since the period of growth (stalks are not formed above water level, but may persist there). Growths of this diatom may not be as visible under periods of high flow, but they can form large amounts of biomass which is later exposed by declining water levels. In contrast to other blooms in North America, a large number of Trichoptera (aquatic caddis fly larvae, likely of the genus Brachycentrus) were present in many survey sites, particularly below Rockefeller Preserve. The caddis fly larvae were apparently grazing on $D$. geminata cells and stalks with much of the biomass removed from the cobbles. This observation suggests that blooms of $D$. geminata may be moderated by these grazing macroinvertebrates.

Figure 3. Images of the bloom of Didymosphenia geminata on Lake Creek in August 2008. A) Site at Lake Creek, near the Rockefeller Preserve with $80 \%$ coverage of the streambed by diatoms and their stalks. Note that some of the stalks are above water level, indicating that streamflow had declined since the period of growth (stalks are not formed above water level, but may persist there), B) Large number of Trichoptera (aquatic caddis fly larvae) apparently grazing on $D$. geminata cells and stalks, C) Underwater image diatoms, their stalks and caddis fly larvae and D) Underwater image diatoms, their stalks and caddis fly larvae. 
One hundred and seventy samples (Appendix 1) were collected for microscopic analysis of cells. Slides were scanned for the presence of stalk forming diatoms, including several species of Gomphoneis, Cymbella mexicana, C. janischii, and Gomphonema olivaceum. These taxa are capable of forming macroscopic growths in streams, rivers and lakes. There were no large growths, however, observed of these taxa. The microscopic presence of $D$. geminata was confirmed in several Lake Creek sites, including Lake Creek above Phelps Lake, as well as in Kaufmann Creek and Taggart Creek. Surveys of the coverage and extent of cells at these sites, however, were not initiated.

An extensive survey of the Snake River was completed below Jackson Dam. No blooms or excessive growths were observed. Microscopic examination of slides from over 100 samples resulted in the confirmation of one cell of $D$. geminata. That sample (\#10859), however, contained a silica frustule (cell wall) was rather degraded and likely does not represent a population in the Snake River itself. Permanent mounts of these samples and the raw material are archived at the INSTAAR Diatom Collection and serve as a resource to determine future expansion in range of $D$. geminata.

Thirty-one samples were analyzed for ash-free dry mass (AFDM) from Lake Creek and the Snake River (Figure 4). Sample values ranged from detection limits to $0.87\left(\mathrm{grams} / 20 \mathrm{~cm}^{2}\right)$. While the samples that lack $D$. geminata were all below 0.2 grams $/ 20 \mathrm{~cm}^{2}$, samples with $D$. geminata present ranged up to several fold that concentration at $0.9 \mathrm{grams} / 20 \mathrm{~cm}^{2}$. In other words, in sites with a bloom of $D$. geminata, the biomass produced reached greater values than at sites without $D$. geminata. The presence of this diatom is associated with high amounts of organic material produced in streams.

\section{Conclusions}

We determined that a nuisance bloom of the diatom Didymosphenia geminata was present in Lake Creek from the outlet of Phelps Lake to approximately $1 \mathrm{~km}$ downstream of the Rockefeller Preserve. This bloom was considered "excessive" because the coverage of the stream substrate was $70 \%$ or above for greater than $1 \mathrm{~km}$. At these sites the total amount of biomass (measured as AFDM) was up to six-fold the biomass found at sites without $D$. geminata.

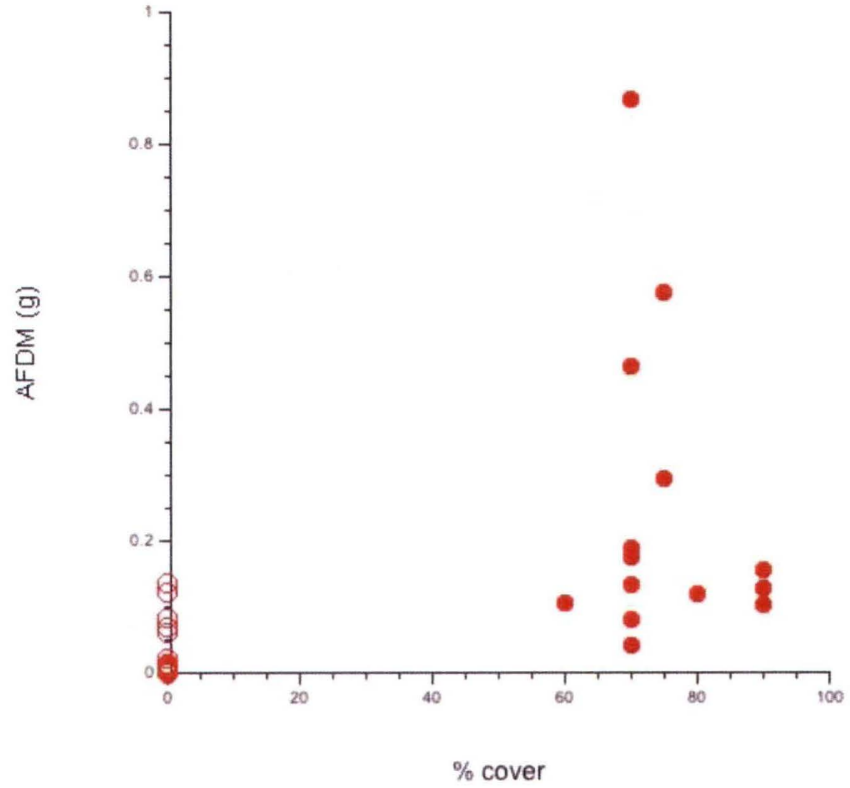

Figure 4. Plot of AFDM (grams $/ 20 \mathrm{~cm}^{2}$ ) against \% cover of stalked diatoms from the Snake River (open circles) and Lake Creek (closed circles).

In addition to Lake Creek, other streams (Kaufmann Creek and Taggart Creek) had visible masses of D. geminata, but the stream extent and coverage was not quantified. Species identification was confirmed based on microscopic examination at those sites. The diatom was also confirmed in Fish Creek by microscopic examination; no visible masses were observed. Sites without both visible blooms and microscopic occurrences were at Arizona Creek, Spread Creek, Buffalo Fork, Cottonwood Creek, Snake River (with except of a single degraded cell) and the Gros Ventre River.

Although there have been attempts to relate the occurrence of $D$. geminata to specific water chemistry and geologic influence, chemical and physical factors seem to represent only a portion of the control on growth and distribution (Lindstrom 1991, Sherbot \& Bothwell 1993, Jónsson et al. 2000, Kilroy 2004). Therefore, it is difficult to state whether water chemistry is controlling the formation of the blooms in GTNP. However, there is indication that these species may be favored under some conditions of increased human impact. Types of human influence that are associated with $D$. geminata blooms include increased nutrient concentration (Kara, \& Şahin 2001, Kawecka \& Sanecki 2003, Noga 2003, Subakov-Simić \& Cvijan 2004), stable flow below impoundments (Dufford et al. 1987, Holderman \& Hardy 2004, Shelby 2006), low flows (Kilroy et al. 2005a), and spread by aquatic 
recreationalists (Kilroy et al. 2005b, Kilroy et al. 2006, Larned et al. 2006). In particular, recent blooms on the east coast of the US in sites with heavy fishing pressure point to the role humans may play in spreading the diatom. The relationship, however, has not been fully documented (Bothwell, personal communication).

We know that $D$. geminata is able to survive out of water, and it may be transported on the gear of recreationalists (Kilroy et al. 2005b). In GTNP, this diatom was found in a high visitor use area, and there is the potential for the species to spread by anglers to other sites within the national park and other public and private lands. Although there are several factors that appear to influence its distribution, recent nuisance blooms of this species suggest popular angling sites are often sites of nuisance blooms. Decontamination of aquatic gear used by recreationalists should reduce the spread of $D$. geminata and the frequency of nuisance blooms within the national park system and adjacent public and private water bodies

\section{ACKNOWLEDGEMENTS}

Thank you to field crew members Sarah Rushforth, Tom Johnson, George Parrish, Sue ConsoloMurphy, Greg Oberley, Tom Slabe, and Peter Ismert. Any use of trade, product or firm names is for descriptive purposes only and does not imply endorsement by the U.S. Government.

\section{Literature Cited}

Bahls, L. 2004. Northwest Diatoms: a photographic catalogue of species in the Montana Diatom Collection, with ecological optima, associates, and distribution records for the nine northwestern United States. Vol. 1. Hannaea@montana.com

Cleve, P.T. 1894-1896. Synopsis of the Naviculoid Diatoms. Kongliga Sevenska VetenskapsAkademiens Handlingar. Stockholm. (Reprinted 1965, A. Asher and Co., Amsterdam)

Dufford, R.G., H.J. Zimmerman, L.D. Cline and J.V. Ward. 1987. Responses of epilithic algae to regulation of Rocky Mountain streams. Pp. 383-390. In: JF Craig and JB Kemper (eds) Regulated Streams: Advances in Ecology. Plenum Press.
Jónsson, G.S., I.R. Jónsson, M. Bjornsson and S.M. Einarsson. 2000. Using regionalisation in mapping the distribution of the diatom species Didymosphenia geminata (Lyngbya) M. Schmidt In: Icelandic rivers. Verhandlungen Internationale Vereinigung fur Theoretische und Angewandte Limnologie 27: 340-343.

Holderman, C.E. and R. Hardy. 2004. Kootenai River Ecosystem Project: an ecosystem approach to evaluate and rehabilitate a degraded, large riverine ecosystem. Final Report to Bonneville Power Administration, Portland OR. Project No. 1994-049-00, Contract No. 00004029.

Kara, H. and B. Şahin. 2001. Epipelic and epilithic algae of the Değirmendere River (TrabazonTurkey). Turkish Journal of Botany 25:177186.

Kawecka, B. and J. Sanecki. 2003. Didymosphenia geminata in running waters of southern Poland - symptoms of change in water quality? Hydrobiologia 495:193-201.

Kilroy, C. 2004. A new alien diatom, Didymosphenia geminata (Lyngbye) Schmidt: its biology, distribution, effects and potential risks for New Zealand fresh waters. National Institute of Water and Atmospheric Research, New Zealand. Client Report: CHC2004-128. NIWA Project: MEL06505.

Kilroy, C., B. Biggs, N. Blair, P. Lambert, B. Jarvie, K. Dey and K. Robinson. 2005a. Ecological studies of Didymosphenia geminata. National Institute of Water Atmospheric Research, New Zealand. Client Report: CHC2005-123, NIWA Project:

Kilroy, C, T. Snelder and J. Sykes. 2005b. Likely environments in which the nonindigenous freshwater diatom can survive, in New Zealand. National Institute of Water and Research, New Zealand. Consultancy Report 2005-043. 34 p.

Kilroy, C., A. Lagerstedt, A. Davey and K. Robinson. 2006. Studies on the survivability of an exotic, invasive diatom Didymosphenia geminata under a range of environmental conditions. NIWA Client Report: CHC2006-116, NIWA Project MAF06506. 
Kociolek, J.P. and E.F. Stoermer. 1993. Freshwater gomphonemoid preliminary results. Hydrobiologia 269-270:31-38.

Kumar, S.S., U. Chinchkar, S. Nair, P.A. Bharathi and D.Chandramohan. 2009. Seasonal dimethylsulfoniopropionate (DMSP) variability in Dona Paula bay. Estuarine Coastal and Shelf Science 81(3):301-310.

Larned, S., B. Biggs, N. Blair, C. Burns, B. Jarvie, D. Jellyman., C. Kilroy, J. Leathwick, K. Lister, J. Nagels, M. Schallenberg, S. Sutherland, J. Sykes, W. Thompson, K. Vopel and B. Wilcock. 2006. Ecology of Didymosphenia geminata in New Zealand: habitat and ecosystem effects - Phase 2. NIWA Client Report CHC2006-086, NIWA Project MAF06507.

Lindstrom, E.A. 1991. Use of periphyton for monitoring rivers in Norway. Application of previously obtained data to evaluate impacts of acid precipitation. Pp. 139-144. In: Methods in Stream Ecology. B.A. Whitton, et al.(eds). Eugen Rott, Austria

Noga, T. 2003. Dispersion of Didymosphenia geminata in the flowing waters of southern Poland new sites of species occurrence in the Orawska Watershed and the Orawska Basin. Oceanological and Hydrobiological Studies 32:159-170.

Patrick, R. and C. W. Reimer. 1966. The Diatoms of the United States, Exclusive of Alaska and Hawaii. Volume I. Monographs of the Academy of Natural Sciences of Philadelphia, Philadelphia. 688 pp.

Renberg, I. 1990. A procedure for preparing large sets of diatom slides from sediment cores. Journal of Paleolimnology 4:87-90.

Shelby, E.L. 2006. An assessment and analysis of benthic macroinvertebrate communities associated with the appearance of Didymosphenia geminata in the White River below Bull Shoals Dam. Arkansas Dept. of Environmental Quality, Water Planning Division Report.
Sherbot, D.M.J. and Bothwell, M.L. 1993. Didymosphenia geminata (Gomphonemaceae). A review of the ecology of $D$. geminata and the physicochemical characteristics of endemic catchments on Vancouver Island. NHRI Contribution No. 93005. National Hydrology Research Institute, Environment Canada, Saskatoon, Saskatchewan.

Skulberg, O.M. 1982. Effects of stream regulation on algal vegetation. In: Regulated Rivers. Lillehammer, A. and Saltveit, S.J. (eds), Pp. 107-124. Columbia University Press, NY.

Skvortzow, B.W. 1935. Diatomées récoltées par le Père I. Licent au cours de ses voyages dans le Nord de la Chine au bas Tibet, en Mongolie et en Mandjourie. Publications du Musée Hoangho Paiho de Tien Tsin. Tienstsin., 36:1-43.

Spaulding, S.A. and L. Elwell. 2007. Increase in nuisance blooms and geographic expansion of the freshwater diatom Didymosphenia geminata: recommendations for response. White paper $33 \mathrm{pp}$.

Steinman, A.D. and G.A. Lamberti. 1996. Biomass and pigments of algae. In: Methods in Stream Ecology. F.R. Hauer and G.A. Lamberti (eds). Pp. 295-314. Academic Press, San Diego.

Subakov-Simić, G. and M. Cvijan. 2004. Didymosphenia geminata (Lyngb.) M. Schmidt (Bacillariophyta) from the Tisa River (Serbia) - its distribution and specific morphological and ecological characteristics. Algological Studies 114:53-66.

Wellnitz, T.A., R.B. Rader and J.V. Ward. 1996. Importance of light and nutrients in structuring an algal community in a Rocky Mountain Stream. Journal of Freshwater Biology 11:399-413. 
APPENDIX 1. Sample site location and confirmation of $D$. geminata with microscopic examination.

\begin{tabular}{|c|c|c|c|c|}
\hline $\begin{array}{l}\text { INSTAAR } \\
\text { accessnum }\end{array}$ & latitude & longitude & water body & site name \\
\hline 10836 & 43.84455588 & -110.517538 & Snake River & $\begin{array}{l}\text { Pacific Landing to Deadman's Bar reach } \\
\text { PLDB A } 0 \text { right bank }\end{array}$ \\
\hline 10837 & 43.84035691 & -110.515488 & Snake River & $\begin{array}{l}\text { Pacific Landing to Deadman's Bar reach } \\
\text { PLDB A } 2 \text { right bank }\end{array}$ \\
\hline 10838 & 43.83605913 & -110.5144012 & Snake River & $\begin{array}{l}\text { Pacific Landing to Deadman's Bar reach } \\
\text { PLDB A } 4 \text { right bank }\end{array}$ \\
\hline 10839 & 43.83232945 & -110.5162783 & Snake River & $\begin{array}{l}\text { Pacific Landing to Deadman's Bar reach } \\
\text { PLDB A } 6 \text { right bank }\end{array}$ \\
\hline 10840 & 43.83067456 & -110.5218358 & Snake River & $\begin{array}{l}\text { Pacific Landing to Deadman's Bar reach } \\
\text { PLDB A } 8 \text { right bank }\end{array}$ \\
\hline 10841 & 43.81513835 & -110.5357418 & Snake River & $\begin{array}{l}\text { Pacific Landing to Deadman's Bar reach } \\
\text { PLDB A } 10 \text { right bank }\end{array}$ \\
\hline 10842 & 43.84455588 & -110.517538 & Snake River & $\begin{array}{l}\text { Pacific Landing to Deadman's Bar reach } \\
\text { PLDB A } 0 \text { left bank }\end{array}$ \\
\hline 10843 & 43.84035691 & -110.515488 & Snake River & $\begin{array}{l}\text { Pacific Landing to Deadman's Bar reach } \\
\text { PLDB A } 2 \text { left bank }\end{array}$ \\
\hline 10844 & 43.83605913 & -110.5144012 & Snake River & $\begin{array}{l}\text { Pacific Landing to Deadman's Bar reach } \\
\text { PLDB A } 4 \text { left bank }\end{array}$ \\
\hline 10845 & 43.83232945 & -110.5162783 & Snake River & $\begin{array}{l}\text { Pacific Landing to Deadman's Bar reach } \\
\text { PLDB A } 6 \text { left bank }\end{array}$ \\
\hline 10846 & 43.83067456 & -110.5218358 & Snake River & $\begin{array}{l}\text { Pacific Landing to Deadman's Bar reach } \\
\text { PLDB A } 8 \text { left bank }\end{array}$ \\
\hline 10847 & 43.82835278 & -110.5270475 & Snake River & $\begin{array}{l}\text { Pacific Landing to Deadman's Bar reach } \\
\text { PLDB A } 10 \text { left bank }\end{array}$ \\
\hline 10848 & 43.82738327 & -110.530191 & Snake River & $\begin{array}{l}\text { Pacific Landing to Deadman's Bar reach } \\
\text { PLDB B } 0 \text { right bank }\end{array}$ \\
\hline 10849 & 43.8242773 & -110.5334694 & Snake River & $\begin{array}{l}\text { Pacific Landing to Deadman's Bar reach } \\
\text { PLDB B } 2 \text { right bank }\end{array}$ \\
\hline 10850 & 43.81993012 & -110.5333212 & Snake River & $\begin{array}{l}\text { Pacific Landing to Deadman's Bar reach } \\
\text { PLDB B } 4 \text { right bank }\end{array}$ \\
\hline 10851 & 43.81647214 & -110.5295916 & Snake River & $\begin{array}{l}\text { Pacific Landing to Deadman's Bar reach } \\
\text { PLDB B } 6 \text { right bank }\end{array}$ \\
\hline 10852 & 43.81513835 & -110.5357418 & Snake River & $\begin{array}{l}\text { Pacific Landing to Deadman's Bar reach } \\
\text { PLDB B } 10 \text { right bank }\end{array}$ \\
\hline 10853 & 43.82738327 & -110.530191 & Snake River & $\begin{array}{l}\text { Pacific Landing to Deadman's Bar reach } \\
\text { PLDB B } 0 \text { left bank }\end{array}$ \\
\hline 10854 & 43.8242773 & -110.5334694 & Snake River & $\begin{array}{l}\text { Pacific Landing to Deadman's Bar reach } \\
\text { PLDB B } 2 \text { left bank }\end{array}$ \\
\hline 10855 & 43.81993012 & -110.5333212 & Snake River & $\begin{array}{l}\text { Pacific Landing to Deadman's Bar reach } \\
\text { PLDB B } 4 \text { left bank }\end{array}$ \\
\hline 10856 & 43.81647214 & -110.5295916 & Snake River & $\begin{array}{l}\text { Pacific Landing to Deadman's Bar reach } \\
\text { PLDB B } 6 \text { left bank }\end{array}$ \\
\hline 10857 & 43.81326116 & -110.5320863 & Snake River & $\begin{array}{l}\text { Pacific Landing to Deadman's Bar reach } \\
\text { PLDB B } 8 \text { left bank }\end{array}$ \\
\hline 10858 & 43.80901278 & -110.5625906 & Snake River & $\begin{array}{l}\text { Pacific Landing to Deadman's Bar reach } \\
\text { PLDB B } 10 \text { left bank }\end{array}$ \\
\hline 10859 & 43.81444675 & -110.5427566 & Snake River & $\begin{array}{l}\text { Pacific Landing to Deadman's Bar reach } \\
\text { PLDB C } 2 \text { right bank }\end{array}$ \\
\hline 10860 & 43.81190267 & -110.5477213 & Snake River & $\begin{array}{l}\text { Pacific Landing to Deadman's Bar reach } \\
\text { PLDB C } 4 \text { right bank }\end{array}$ \\
\hline 10861 & 43.81064298 & -110.5586633 & Snake River & $\begin{array}{l}\text { Pacific Landing to Deadman's Bar reach } \\
\text { PLDB C } 8 \text { right bank }\end{array}$ \\
\hline 10862 & 43.80901278 & -110.5625906 & Snake River & $\begin{array}{l}\text { Pacific Landing to Deadman's Bar reach } \\
\text { PLDB C } 10 \text { right bank }\end{array}$ \\
\hline 10863 & 43.81646817 & -110.5374271 & Snake River & $\begin{array}{l}\text { Pacific Landing to Deadman's Bar reach } \\
\text { PLDB C } 0 \text { left bank }\end{array}$ \\
\hline 10864 & 43.81444675 & -110.5427566 & Snake River & $\begin{array}{l}\text { Pacific Landing to Deadman's Bar reach } \\
\text { PLDB C } 2 \text { left bank }\end{array}$ \\
\hline 10865 & 43.81190267 & -110.5477213 & Snake River & $\begin{array}{l}\text { Pacific Landing to Deadman's Bar reach } \\
\text { PLDB C } 4 \text { left bank }\end{array}$ \\
\hline 10866 & 43.80990198 & -110.5533528 & Snake River & $\begin{array}{l}\text { Pacific Landing to Deadman's Bar reach } \\
\text { PLDB C } 6 \text { left bank }\end{array}$ \\
\hline 10867 & 43.80901278 & -110.5625906 & Snake River & $\begin{array}{l}\text { Pacific Landing to Deadman's Bar reach } \\
\text { PLDB C } 10 \text { left bank }\end{array}$ \\
\hline
\end{tabular}

notes date

$08 / 20 / 2008$

$08 / 20 / 2008$

Gomphoneis

$08 / 20 / 2008$

spp.

$08 / 20 / 2008$

$08 / 20 / 2008$

Gomphoneis

$08 / 20 / 2008$

spp.

Gomphoneis

08/20/2008

spp.

08/20/2008

08/20/2008

08/20/2008

08/20/2008

08/20/2008

08/20/2008

08/20/2008

08/20/2008

08/20/2008

08/20/2008

08/20/2008

08/20/2008

08/20/2008

08/20/2008

08/20/2008

One cell - D.

$08 / 20 / 2008$

geminata

08/20/2008

08/20/2008

08/20/2008

08/20/2008

08/20/2008

08/20/2008

08/20/2008

08/20/2008

08/20/2008 


\begin{tabular}{|c|c|c|c|c|}
\hline 10868 & 43.80652546 & -110.5617988 & Snake River & $\begin{array}{l}\text { Pacific Landing to Deadman's Bar reach } \\
\text { PLDB D } 0 \text { right bank }\end{array}$ \\
\hline 10869 & 43.79972564 & -110.5653076 & Snake River & $\begin{array}{l}\text { Pacific Landing to Deadman's Bar reach } \\
\text { PLDB D } 5 \text { right bank }\end{array}$ \\
\hline 10870 & 43.80652546 & -110.5617988 & Snake River & $\begin{array}{l}\text { Pacific Landing to Deadman's Bar reach } \\
\text { PLDB D } 0 \text { left bank }\end{array}$ \\
\hline 10871 & 43.79972564 & -110.5653076 & Snake River & $\begin{array}{l}\text { Pacific Landing to Deadman's Bar reach } \\
\text { PLDB D } 5 \text { left bank }\end{array}$ \\
\hline 10872 & 43.80006302 & -110.5741966 & Snake River & $\begin{array}{l}\text { Pacific Landing to Deadman's Bar reach } \\
\text { PLDB D } 10 \text { left bank }\end{array}$ \\
\hline 10873 & 43.79814517 & -110.5783102 & Snake River & $\begin{array}{l}\text { Pacific Landing to Deadman's Bar reach } \\
\text { PLDB E } 0 \text { right bank }\end{array}$ \\
\hline 10874 & 43.78572082 & -110.5828692 & Snake River & $\begin{array}{l}\text { Pacific Landing to Deadman's Bar reach } \\
\text { PLDB E } 5 \text { right bank }\end{array}$ \\
\hline 10875 & 43.79814517 & -110.5783102 & Snake River & $\begin{array}{l}\text { Pacific Landing to Deadman's Bar reach } \\
\text { PLDB E } 0 \text { left bank }\end{array}$ \\
\hline 10876 & 43.78572082 & -110.5828692 & Snake River & $\begin{array}{l}\text { Pacific Landing to Deadman's Bar reach } \\
\text { PLDB E } 5 \text { left bank }\end{array}$ \\
\hline 10876 & 43.77690297 & -110.5833632 & Snake River & $\begin{array}{l}\text { Pacific Landing to Deadman's Bar reach } \\
\text { PLDB E } 10 \text { left bank }\end{array}$ \\
\hline 10877 & 43.77657385 & -110.5858459 & Snake River & $\begin{array}{l}\text { Pacific Landing to Deadman's Bar reach } \\
\text { PLDB F } 0 \text { right bank }\end{array}$ \\
\hline 10878 & 43.7704316 & -110.5949721 & Snake River & $\begin{array}{l}\text { Pacific Landing to Deadman's Bar reach } \\
\text { PLDB F } 5 \text { right bank }\end{array}$ \\
\hline 10879 & 43.7704316 & -110.5949721 & Snake River & $\begin{array}{l}\text { Pacific Landing to Deadman's Bar reach } \\
\text { PLDB F } 5 \text { left bank }\end{array}$ \\
\hline 10880 & 43.76131735 & -110.6006531 & Snake River & $\begin{array}{l}\text { Pacific Landing to Deadman's Bar reach } \\
\text { PLDB F } 10 \text { left bank }\end{array}$ \\
\hline 10881 & 43.76025713 & -110.6035316 & Snake River & $\begin{array}{l}\text { Pacific Landing to Deadman's Bar reach } \\
\text { PLDB G } 0 \text { right bank }\end{array}$ \\
\hline 10882 & 43.86153733 & -110.5740036 & Snake River & $\begin{array}{l}\text { Jackson Dam to Pacific Landing reach } \\
\text { JDPL A } 5 \text { left bank }\end{array}$ \\
\hline 10883 & 43.86163161 & -110.5653294 & Snake River & $\begin{array}{l}\text { Jackson Dam to Pacific Landing reach } \\
\text { JDPL A } 8 \text { left bank }\end{array}$ \\
\hline 10884 & 43.86034305 & -110.5629094 & Snake River & $\begin{array}{l}\text { Jackson Dam to Pacific Landing reach } \\
\text { JDPL A } 9 \text { left bank }\end{array}$ \\
\hline 10885 & 43.8561945 & -110.555178 & Snake River & $\begin{array}{l}\text { Jackson Dam to Pacific Landing reach } \\
\text { JDPL B } 1 \text { left bank }\end{array}$ \\
\hline 10886 & 43.85654022 & -110.5522552 & Snake River & $\begin{array}{l}\text { Jackson Dam to Pacific Landing reach } \\
\text { JDPL B } 2 \text { left bank }\end{array}$ \\
\hline 10887 & 43.85823735 & -110.5499609 & Snake River & $\begin{array}{l}\text { Jackson Dam to Pacific Landing reach } \\
\text { JDPL B } 3 \text { left bank }\end{array}$ \\
\hline 10888 & 43.84934312 & -110.5375782 & Snake River & $\begin{array}{l}\text { Jackson Dam to Pacific Landing reach } \\
\text { JDPL B } 10 \text { left bank - sample \#1 }\end{array}$ \\
\hline 10889 & 43.84934312 & -110.5375782 & Snake River & $\begin{array}{l}\text { Jackson Dam to Pacific Landing reach } \\
\text { JDPL B } 10 \text { left bank - sample \#2 }\end{array}$ \\
\hline 10890 & 43.84807404 & -110.5347935 & Snake River & $\begin{array}{l}\text { Jackson Dam to Pacific Landing reach } \\
\text { JDPL C } 0 \text { left bank }\end{array}$ \\
\hline 10891 & 43.84871455 & -110.5313868 & Snake River & $\begin{array}{l}\text { Jackson Dam to Pacific Landing reach } \\
\text { JDPL C } 1 \text { left bank }\end{array}$ \\
\hline 10892 & 43.84880884 & -110.5281811 & Snake River & $\begin{array}{l}\text { Jackson Dam to Pacific Landing reach } \\
\text { JDPL C } 2 \text { left bank }\end{array}$ \\
\hline 10893 & 43.84846313 & -110.5249125 & Snake River & $\begin{array}{l}\text { Jackson Dam to Pacific Landing reach } \\
\text { JDPL C } 3 \text { left bank }\end{array}$ \\
\hline 10894 & 43.84783456 & -110.5218325 & Snake River & $\begin{array}{l}\text { Jackson Dam to Pacific Landing reach } \\
\text { JDPL C } 4 \text { left bank }\end{array}$ \\
\hline 10895 & 43.85690028 & -110.5584696 & Snake River & $\begin{array}{l}\text { Jackson Dam to Pacific Landing reach } \\
\text { JDPL B } 0 \text { right bank }\end{array}$ \\
\hline 10896 & 43.8561945 & -110.555178 & Snake River & $\begin{array}{l}\text { Jackson Dam to Pacific Landing reach } \\
\text { JDPL B } 1 \text { right bank }\end{array}$ \\
\hline 10897 & 43.85823735 & -110.5499609 & Snake River & $\begin{array}{l}\text { Jackson Dam to Pacific Landing reach } \\
\text { JDPL B } 3 \text { right bank }\end{array}$ \\
\hline 10898 & 43.85999734 & -110.5483267 & Snake River & $\begin{array}{l}\text { Jackson Dam to Pacific Landing reach } \\
\text { JDPL B } 4 \text { right bank }\end{array}$ \\
\hline 10899 & 43.8587402 & -110 & Snake River & $\begin{array}{l}\text { Jackson Dam to Pacific Landing reach } \\
\text { JDPL B } 5 \text { right bank }\end{array}$ \\
\hline 10900 & 43.85635165 & -110.5452467 & Snake River & $\begin{array}{l}\text { Jackson Dam to Pacific Landing reach } \\
\text { JDPL B } 6 \text { right bank }\end{array}$ \\
\hline 10901 & 43.85415166 & -110.5444924 & Snake River & $\begin{array}{l}\text { Jackson Dam to Pacific Landing reach } \\
\text { JDPL B } 7 \text { right bank }\end{array}$ \\
\hline 10902 & 43.85236024 & -110.542261 & Snake River & $\begin{array}{l}\text { Jackson Dam to Pacific Landing reach } \\
\text { JDPL B } 8 \text { right bank }\end{array}$ \\
\hline
\end{tabular}

08/20/2008

08/20/2008

08/20/2008

$08 / 20 / 2008$

08/20/2008

$08 / 20 / 2008$

$08 / 20 / 2008$

$08 / 20 / 2008$

$08 / 20 / 2008$

$08 / 20 / 2008$

08/20/2008

$08 / 20 / 2008$

$08 / 20 / 2008$

08/20/2008

08/20/2008

08/20/2008

08/20/2008

08/20/2008

08/20/2008

08/20/2008

08/20/2008

08/20/2008

08/20/2008

08/20/2008

08/20/2008

08/20/2008

08/20/2008

08/20/2008

08/20/2008

08/20/2008

08/20/2008

08/20/2008

08/20/2008

08/20/2008

08/20/2008

08/20/2008 


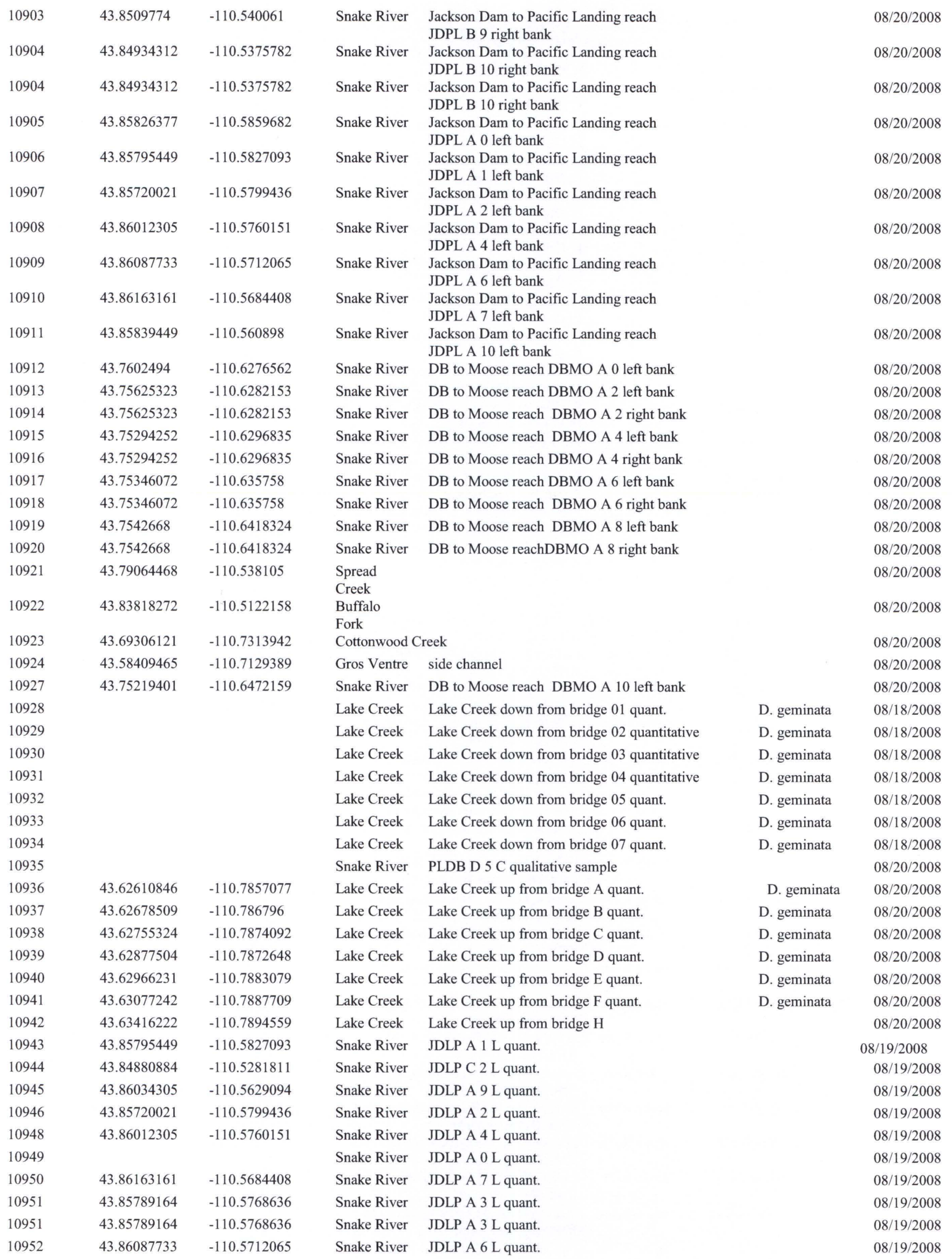




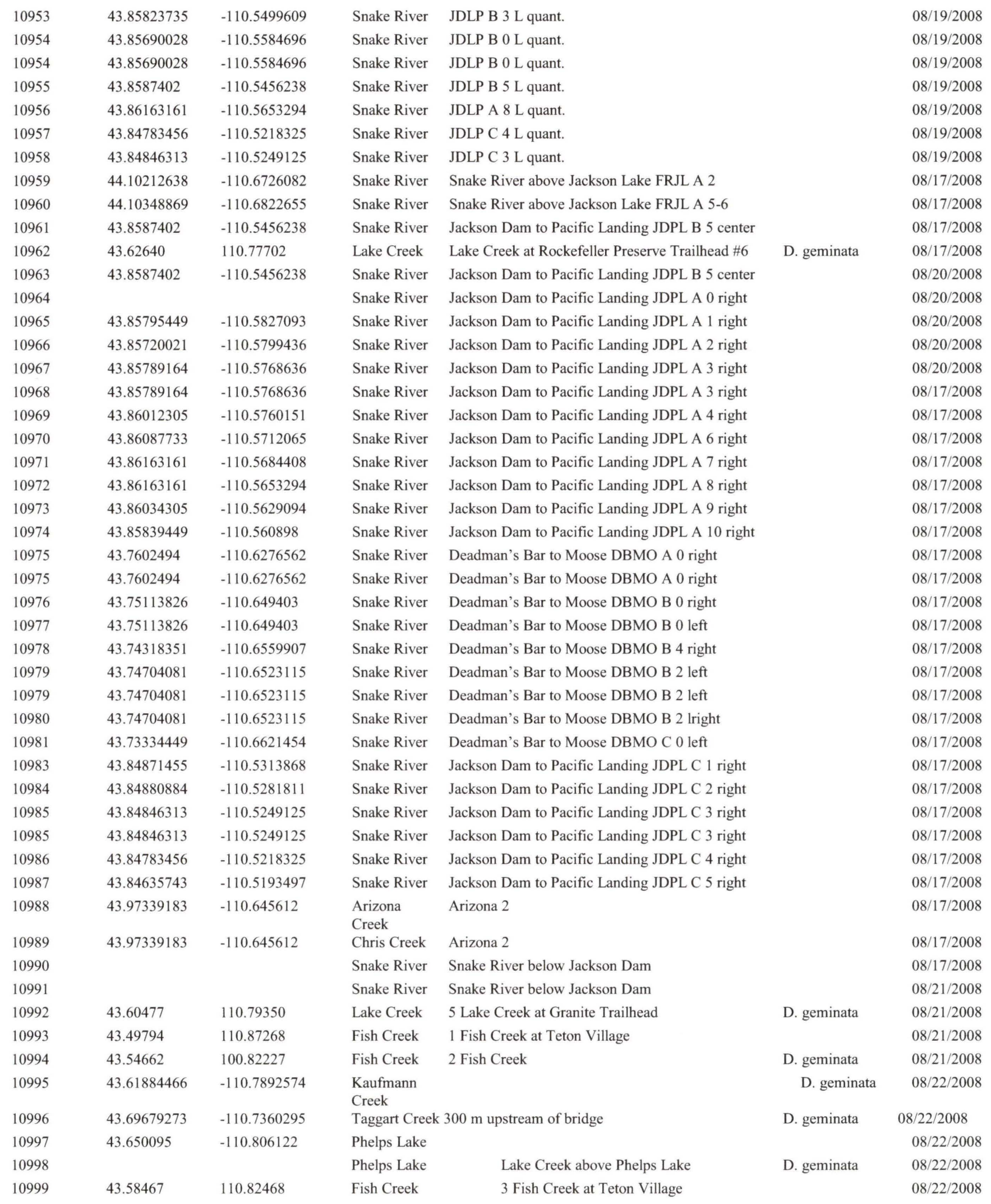

